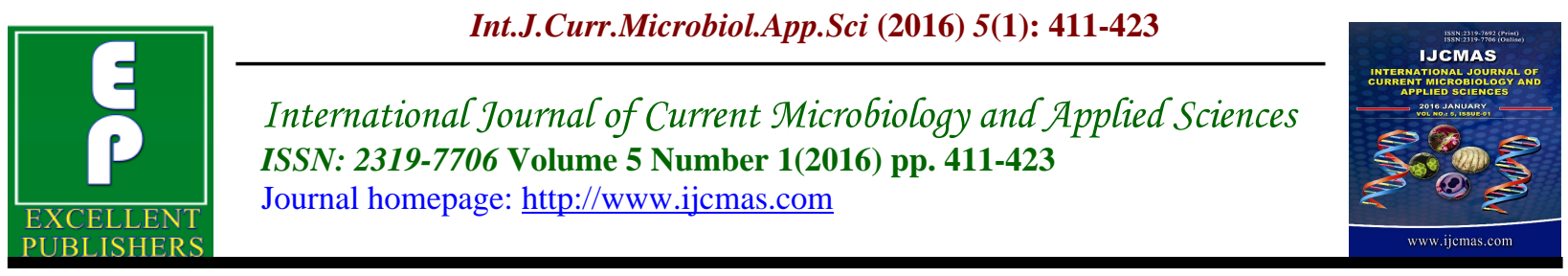

Original Research Article

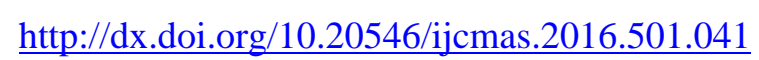

\title{
Beneficial Effects of Diet Supplementation with Nigella sativa (Black Seed) and Sesame Seeds in Alloxan-Diabetic Rats
}

\author{
Thanaa A.A. Ibrahiem* \\ Family and Child Sciences Department - Nutrition and Food Science, \\ Faculty of Arts and Sciences, Qassim University, Onaizh Soudia, Saudi Arabia \\ *Corresponding author
}

\section{Keywords}

Nigella sativa;

Sesame

seeds;

Immunostimulant,

Antidiabetic,

Antioxidant

\section{Article Info}

Accepted:

18 December 2015

Available Online:

10 January 2016

\section{A B S T R A C T}

This study was performed to assess the effect of diet supplementation with Nigella sativa (NS) and Sesame seeds (SS) on body weight, immune status, blood glucose (BG), insulin, total cholesterol (TC), triglycerides (TG) and kidney function parameters as well as on activities of renal tissue antioxidant enzymes in diabetic rats. Forty nine mature Sprague Dawley male rats were randomized into 7 groups $(n=7)$. Group (1) was used as a negative control and fed on basal diet, while the remaining 6 groups were rendered diabetic by intraperitoneal injection of alloxan $(120 \mathrm{mg} / \mathrm{kg})$. After induction of diabetes, group (2) was kept positive control, while groups (3), (4), (5), (6) and (7) were fed on diet supplemented with $5 \%$ NS; $10 \%$ NS; $5 \%$ SS; $10 \%$ SS and 5\% NS+ 5\% SS, respectively for 6 weeks. The initial and final body weights of rats were recorded. Blood samples were collected for estimation of tumor necrosis factor alpha (TNF- $\alpha$ ), inflammatory cytokines IL-4 and IL-8, fasting BG, insulin, TC and TG levels, blood urea nitrogen (BUN), uric acid and creatinine (Cr) serum levels. Differential leucocytic count and activities of antioxidant enzymes superoxide dismutase (SOD), glutathione peroxidase (GPx) and catalase (CAT) in kidney tissues were also determined. The results showed that diet supplementation with NS and SS significantly increased body weight and improved feed efficiency ratio of diabetic rats. Diet supplementation with NS and SS decreased the number of lymphocytes, decreased production of TNF- $\alpha$ and cytokines IL4 and IL8; normalized BG, insulin, TC and TG and BUN and Cr levels. There were enhanced the activity of SOD, GPx and CAT enzymes in renal tissues of diabetic rats. In conclusion, diet supplementation with NS and SS has immunostimulant, antidiabetic, hypolipidemic, nephroprotective and antioxidant activities in diabetic rats. Therefore, intake of baked foods and sweets supplemented with NS and SS may be beneficial for patients who suffer from diabetes mellitus.

\section{Introduction}

Diabetes mellitus (DM) is a chronic metabolic disease characterized by hyper- glycemia due to insulin deficiency or insulin resistance or both. DM is accompanied with 
metabolic, vascular, nephropathic and neuropathic disorders (Gale and Anderson, 2009). The metabolic disorder of DM is frequently diagnosed by hyperglycemia and lipid abnormalities leading to vascular disorders. Hyperglycemia occurs when the cells become unable to utilize glucose and/or the liver and skeletal muscles cannot store glycogen (Luis-Rodríguez et al., 2012). The capacity of the innate immune system to sense metabolic stress induced by nutritional surplus has been linked with the progression of obesity and type 2 DM (Jin et al., 2013). Activation of the innate immunity evident by increased secretion of inflammatory cytokines has been shown to be relevant to the pathogenesis of DM type 2 (Itariu and Stulnig et al. 2014). In addition, DM induced oxidative stress via generation of reactive oxygen species (ROS) that are causally linked to the development of cardiovascular morbidity and mortality (Sturza et al., 2015).

Nigella sativa (NS) seeds have been used for thousands of years for culinary and medical purposes. Many of the biological activities of NS were attributed to presence of thymoquinone (TQ) in the essential oil (Houghton et al., 1995). TQ is the most abundant bioactive ingredient of NS essential oil and mediates most of therapeutic effects. TQ and seeds of Ns were reported to produce antioxidant (Badary et al., 1997); antidiabetic (Kaleem et al. 2006); anticancer (Gali-Muhtasib et al., 2006 and Randhawa and Alghamdi, 2011); analgesic and anti-inflammatory (Inci et al., 2013) and hypolipidemic (Ahmad and Beg, 2013 and Asgary et al., 2015) effects. The seeds of NS have been found by some authors to possess an immunopotential activity (Haq et al., 1995; El-Feki et al., 1997; Assayed, 2010 and Sultan et al., 2014).
Sesame seeds (SS) have been used as a source of healthful foods and of essential Sesame oil. The seeds are a rich source of many essential minerals. Sesame oil is one of the most stable vegetable oils and it contains high content of natural antioxidant lignans as sesamin, sesamolin and sesamol (Mahendra and Singh, 2015). Defatted Sesame seeds have been reported for hypoglycemic effect in mice and women with DM type2 (Wikul et al., 2012). Sesamin induced an antihypertensive effect in humans (Miyawaki et al., 2009); improved serum triglycerides and atherogenic lipid parameters in type 2 diabetic patients (Mirmiran et al., 2013). Sesamin produced protective effect against CCL4-induced hepatotoxicity in mice (Ma et al., 2014) and anticancer activity against human breast cancer (Siao, et al., 2015).

The present study was designed to evaluate the effect of fortification of diets with Nigella sativa and Sesame seeds on body weight, immune status; blood glucose, insulin, total cholesterol and triglycerides levels as well as kidney function parameters and the activity of renal antioxidant enzymes in alloxan-diabetic rats.

\section{Materials and Methods}

\section{Plant Seeds}

Nigella sativa (Black seed, Family Ranunculaceae) and Sesame (Family Pedaliaceae) seeds were purchased from local store of spices, grains and oils, Cairo, Egypt. Both seeds were grinded into a fine powder using an electric coffee mixer. Each powder was added to the basal diet at 5 and $10 \%$ concentrations and combination of both powders at $5 \%$ to formulate the experimental diets. 


\section{Rats}

Forty nine (49) mature male Sprague Dawley rats weighing 250-255 g b.wt and 10-11 weeks old were used in this study. The rats were purchased from Laboratory Animal Colony, Helwan, Egypt. The animals were housed individually in metabolic cages under hygienic conditions at room temperature of $25{ }^{\circ} \mathrm{C}$, relative humidity of $50 \%$ and $12 \mathrm{hr}$ light/12 hr dark cycles. The rats were fed on either basal or experimental diets during feeding period and water was provided ad libitum.

\section{Alloxan and Biochemical Kits}

Alloxan was purchased from El-Gomhoryia Company for Chemicals; Cairo, Egypt. It is dispensed in the form of white powder packed in tightly closed brown bottles each containing $25 \mathrm{~g}$ alloxan monohydrate. Kits for biochemical determinations of blood glucose and insulin hormone Kits (enzymelinked immunoassay) were purchased from Gamma Trade Company, Egypt. The other biochemical kits were obtained from Biodiagnostic Company, Dokki, Egypt.

\section{Basal and Experimental Diets}

The dietary supply of protein, fat, carbohydrates, vitamins and minerals was in accordance with the recommended dietary allowances for rats (American Institute of Nutrition, AIN) according to Reeves et al. (1993). Basal diet was consisted of $20 \%$ protein, $10 \%$ sucrose, $5 \%$ corn oil, $2 \%$ choline chloride, $1 \%$ vitamin mixture, $3.5 \%$ salt mixture and $5 \%$ fibers. The remainder was corn starch up to $100 \%$.

Five experimental diets were thoroughly formulated as follow:

1- Basal diet supplemented with $5 \%$ Nigella sativa seeds (NS) powder
2- Basal diet supplemented with $10 \%$ NS powder

3- Basal diet supplemented with 5\% Sesame seeds (SS) powder

4- Basal diet supplemented with $10 \%$ SS powder

5- Basal diet supplemented with 5\% NS+ $5 \% \mathrm{SS}$

\section{Experimental Design}

Rats were randomized into to 7 groups of 7 animals each. Group (1) was used as negative control and fed on basal diet, while the other 6 groups were rendered diabetic. Diabetes mellitus was induced by single intraperitoneal injection of alloxan in a dose of $120 \mathrm{mg} / \mathrm{kg} /$ day as described by Ashok et al., (2007). Fasting blood glucose levels were determined and rats with glucose levels between 250 to $300 \mathrm{mg} / \mathrm{dL}$ were considered diabetic. After induction of diabetes, group (2) was kept positive (diabetic) control and fed on basal diet, while groups (3), (4), (5) and (6) were fed on experimental diets supplemented with $5 \%$ NS; $10 \%$ NS; $5 \%$ SS; $10 \%$ SS and 5\% NS+5\%SS, respectively for 6 weeks. During feeding period, the initial and final body weights of rats were recorded and changes in body weight and feed efficiency were calculated. At the end of experiment, blood samples were collected for biochemical analyses.

\section{Biochemical Analyses}

Blood samples were withdrawn by cardiac puncture, left standing for 10 minutes to clot and centrifuged at $8000 \mathrm{rpm}$ for 10 minutes to separate the serum which kept frozen at $18^{\circ} \mathrm{C}$ till biochemical analyses. Serum concentrations of tumor necrosis factor alpha (TNF- $\alpha)$ as a proinflammatory cytokine and inflammatory cytokines IL-4 and IL-8 in blood samples were determined by enzyme-linked immunosorbent assay 
(ELISA) using commercially available kits according to the manufacturer's instructions (R\&D Systems Inc., Minneapolis, MN, USA). Fasting blood glucose was chemically determined using glucose enzymatic kit according to Siest et al. (1981) and Insulin was estimated using radioimmunoassay (RIA) assay (Yallow and Bauman, 1983). Serum levels of total cholesterol and triglycerides were chemically determined according to Ratliff and Hall (1973) and Jacob and VanDenmark (1963), respectively.

\section{Differential Leucocytic Count}

Freshly collected blood samples of $20 \mu \mathrm{l}$ were spread on clean slides as a thin film. Each smear was left to air dried and fixed with methanol for $2-3 \mathrm{~min}$ and then labelled. Blood smears were stained with $10 \%$ Giemsa's stain (Aldrich), examined under light microscopy and different types of blood leukocytes were counted (Schalm et al., 1975).

\section{Kidney Function}

For assessment of kidney function, the concentration of blood urea nitrogen (BUN) was determined using BioMérieux kits according to the method of Patton and Crouch, (1977). Serum uric acid (UA) was determined using the enzymatic colorimetric method as described by Fossati et al., (1980). Serum creatinine (Cr) concentration was colorimetrically determined by the Jaffe reaction according to the method of Husdan and Rapoport, (1968).

\section{Assay of Tissue Antioxidant Enzymes}

One gram of kidney tissue was washed with ice-cooled $0.9 \% \mathrm{NaCl}$ solution and homogenized in $100 \mathrm{ml}$ of ice-cooled $1.5 \%$ solution of potassium chloride and $50 \mathrm{mmol}$ potassium phosphate buffer solutions $(\mathrm{pH}$
7.4) to yield $1 \%$ homogenate (W/V). Homogenization was performed using Sonicator, 4710 Ultrasonic Homogenizer. Kidney homogenates were centrifuged at $4000 \mathrm{rpm}$ for 10 minutes at $4^{\circ} \mathrm{C}$ and the supernatants were used to assay the activity of antioxidant enzymes glutathione peroxidase (GPx), superoxide dismutase (SOD), and catalase (CAT) according to Paglia and Valentaine (1979), Spitz and Oberley (1989), and Sinha (1972), respectively.

\section{Statistical Analysis}

Data were presented as means \pm SD. Statistical analysis was performed using computerized Statistical Package of Social Sciences (SPSS) program with one-way analysis of variance (ANOVA) followed by Duncan's multiple range tests according to Snedecor and Cochran (1986).

\section{Results and Discussion}

Diabetic rats gained less body weight and had decreased feed efficiency ratio as compared to negative (normal) control rats. Feeding diabetic rats on diets supplemented with NS and SS and their combination significantly $(P<0.05)$ increased body weight gain and improved feed efficiency ratio when compared with the positive (diabetic) control group (Table 1).

The results of ELISA test showed that diabetes mellitus in rats induced significant $(P<0.05)$ increases in serum tumor necrosis factor alpha (TNF- $\alpha)$ and inflammatory cytokines IL4 and IL8. Experimental diets supplemented with NS and SS and their combination significantly $(P<0.05)$ decreased the elevated levels of serum TNF$\alpha$, IL4 and IL8 in diabetic rats when compared to the positive (diabetic) control group (Table 2). 
Results showed that neutrophils percentage in the diabetic group was higher than both in the normal control group and the diabetic group treated with NS, SS and their combination. On the other hand, lymphocytes percentage in the diabetic group was slightly lower than both the normal control group and the diabetic group treated with NS and SS and their combination. In parallel to neutrophils, monocytes percentage in the diabetic group was higher than in the control group and the diabetic group treated with NS and SS and their combination. Feeding experimental diets supplemented with NS and SS and their combination increased neutrophils and monocytes percentages, but decreased lymphocytes percentage when compared with the normal control group (Table, 3 ).

Data in Table (4) showed that diabetes in rats significantly increased blood glucose and decreased insulin levels when compared to the normal control non diabetic group. Diets supplemented with NS and SS and their combination significantly decreased blood glucose and increased insulin levels as compared with the positive (diabetic) control group.

Diabetes in rats significantly increased serum total cholesterol (TC) and triglycerides (TG). Diets supplementation with NS and SS and their combination significantly decreased the elevated serum levels of TC and TG as compared with the positive (diabetic) control group (Table 5).

Diet supplemented with Nigella sativa (NS) and Sesame seeds (SS) significantly improved kidney function as it significantly decreased the elevated levels of blood urea nitrogen (BUN) and creatinine $(\mathrm{Cr}$.) as recorded in Table (6).

The results showed that feeding diet supplemented with Nigella sativa (NS) and Sesame seeds (SS) to diabetic rats significantly increased the activity of renal tissue antioxidant enzymes superoxide dismutase (SOD), glutathione peroxidase (GPx), and catalase (CAT) as recorded in Table (7).

The present study aimed to evaluate the effect of diet supplemented with Nigella sativa (NS) and Sesame seeds (SS) and their combination on body weight, immune status, blood glucose (BG), insulin, total cholesterol (TC), triglycerides (TG), blood urea nitrogen (BUN), uric acid (UA) and creatinine $(\mathrm{Cr})$ levels as well as activities of renal tissue antioxidant enzymes in diabetic rats.

Alloxan has been known to be diabetogenic and induces DNA strand breaks in isolated rat pancreatic islets in vitro to cause Diabetes mellitus (Okamoto, 1985). This is in accordance with our data, where alloxan injection induced significant increase in blood glucose levels versus the control (non diabetic) group. The rise in blood glucose was significantly reduced after feeding diets supplemented with Nigella sativa (NS) and Sesame seeds (SS) compared to the normal and diabetic groups. The mechanism of action of NS and SS to decrease glucose concentrations in diabetes mellitus is still unknown. Oral supplementation of NS after alloxan treatment caused low plasma glucose levels and high serum insulin values. The NS and SS might be involved in reducing or inhibiting alloxan DNA strand breaks, increasing insulin secretion and consequently decreasing the glucose level Akhtar and Ali (1984).

Free radicals are chemically unstable atoms that cause damage to cell lipids, proteins and DNA due to imbalance between the generation of reactive oxygen species (ROS) 
and the antioxidant enzymes. Free radicals are known to be the main cause of oxidative stress which is grossly implicated in the pathogenesis of various diseases such as cancer, diabetes and cardiovascular diseases. Natural antioxidants have been gained much attention from consumers because they are considered safer than synthetic antioxidants. Natural antioxidants derived from fruits, vegetables, spices, and cereal grains are very effective and can protect the human body from oxidative stress caused by ROS (Sreeramulu and Raghunath, 2010).

Table.1 Effect of Diets Fortified with Nigella Sativa (NS) and Sesame Seeds (SS) on - 7 Body Weight Gain (BWG) and Feed Efficiency Ratio (FER) in Diabetic Rats

\begin{tabular}{|lllll|}
\hline & Initial b.wt. & Final b.wt. & BWG & FER \\
\hline $\begin{array}{l}\text { Group 1 } \\
\text { Normal control }\end{array}$ & $255.0 \pm 7.5^{\mathbf{a}}$ & $300.0 \pm 7.3^{\mathbf{a}}$ & 17.74 & $1.20 \pm 0.04^{\mathbf{a}}$ \\
\hline $\begin{array}{l}\text { Group 2 } \\
\text { Diabetic control }\end{array}$ & $250.0 \pm 7.3^{\mathbf{a}}$ & $275.0 \pm 6.1^{\mathbf{c}}$ & 10.00 & $0.45 \pm 0.01^{\mathbf{c}}$ \\
\hline $\begin{array}{l}\text { Group 3 } \\
5 \% \text { NS }\end{array}$ & $254.0 \pm 7.6^{\mathbf{a}}$ & $285.0 \pm 4.2^{\mathbf{b}}$ & 12.21 & $0.90 \pm 0.02^{\mathbf{b}}$ \\
\hline $\begin{array}{l}\text { Group 4 } \\
10 \% \text { NS }\end{array}$ & $252.5 \pm 6.9^{\mathbf{a}}$ & $288.0 \pm 6.3^{\mathbf{b}}$ & 14.05 & $0.92 \pm 0.03^{\mathbf{b}}$ \\
\hline $\begin{array}{l}\text { Group 5 } \\
5 \% \text { SS }\end{array}$ & $251.0 \pm 7.1^{\mathbf{a}}$ & $289.0 \pm 5.9^{\mathbf{b}}$ & 15.13 & $0.90 \pm 0.01^{\mathbf{b}}$ \\
\hline $\begin{array}{l}\text { Group 6 } \\
10 \% \text { SS }\end{array}$ & $253.5 \pm 6.9^{\mathbf{a}}$ & $294.0 \pm 5.9^{\mathbf{a}}$ & 15.97 & $0.95 \pm 0.01^{\mathbf{b}}$ \\
\hline $\begin{array}{l}\text { Group 7 } \\
5 \% \text { NS }+5 \% \text { SS }\end{array}$ & $254.0 \pm 6.3^{\mathbf{a}}$ & $295.0 \pm 6.2^{\mathbf{a}}$ & 16.14 & $1.11 \pm 0.01^{\mathbf{a}}$ \\
\hline
\end{tabular}

Means \pm SD with different superscript letters in the same column are significant at $P<0.05$ using one way ANOVA test. $\mathrm{n}=7$ rats

Table.2 Effect of Diets Fortified with Nigella Sativa (NS) and Sesame Seeds (SS) on Serum Tumor Necrosis Factor Alpha (TNF- $\alpha$ ) Interleukins IL-4 and IL-8 in Diabetic Rats

\begin{tabular}{|c|c|c|c|}
\hline \multirow[b]{2}{*}{ Groups } & \multicolumn{3}{|c|}{ Serum concentration of } \\
\hline & $\begin{array}{l}\mathrm{TNF}-\alpha \\
(\mathbf{n g} / \mathbf{m l})\end{array}$ & $\begin{array}{l}\text { IL4 } \\
(\mathrm{pg} / \mathrm{ml})\end{array}$ & $\begin{array}{c}\text { IL8 } \\
(\mathrm{pg} / \mathrm{ml})\end{array}$ \\
\hline $\begin{array}{l}\text { Group } 1 \\
\text { Normal control }\end{array}$ & $1.95 \pm 0.01^{\mathrm{e}}$ & $855.8 \pm 3.5^{\mathrm{c}}$ & $244.4 \pm 4.3^{e}$ \\
\hline $\begin{array}{l}\text { Group } 2 \\
\text { Diabetic control }\end{array}$ & $4.82 \pm 0.07^{\mathrm{a}}$ & $944.4 \pm 5.3^{\mathrm{a}}$ & $632.1 \pm 3.3^{\mathrm{a}}$ \\
\hline $\begin{array}{l}\text { Group } 3 \\
5 \% \text { NS }\end{array}$ & $2.65 \pm 0.01^{\mathrm{c}}$ & $810.8 \pm 5.2^{\mathrm{d}}$ & $332.2 \pm 5.3^{c}$ \\
\hline $\begin{array}{l}\text { Group } 4 \\
10 \% \text { NS }\end{array}$ & $2.45 \pm 0.02^{c}$ & $813.2 \pm 4.2^{\mathrm{d}}$ & $335.2 \pm 5.3^{c}$ \\
\hline $\begin{array}{l}\text { Group } 5 \\
5 \% \text { SS }\end{array}$ & $3.76 \pm 0.02^{b}$ & $844.5 \pm 2.5^{b}$ & $425.1 \pm 5.3^{b}$ \\
\hline $\begin{array}{l}\text { Group } 6 \\
10 \% \text { SS }\end{array}$ & $3.32 \pm 0.01^{\mathrm{b}}$ & $846.2 \pm 5.2^{b}$ & $427.1 \pm 3.2^{b}$ \\
\hline $\begin{array}{l}\text { Group } 7 \\
5 \% \text { NS }+5 \% \text { SS }\end{array}$ & $2.00 \pm 0.01^{\mathrm{d}}$ & $820 \pm 3.2^{c}$ & $312.2 \pm 2.3^{\mathrm{d}}$ \\
\hline
\end{tabular}

Means \pm SD with different superscript letters in the same column are significant at $P<0.05$ using one way ANOVA test. $\mathrm{n}=7$ rats 
Table.3 Effect of Diets Fortified with Nigella Sativa (NS) and Sesame Seeds (SS) on Differential Leukocyte Count in Diabetic Rats

\begin{tabular}{|c|c|c|c|c|}
\hline & $\begin{array}{c}\text { Neutrophils } \\
(\%)\end{array}$ & $\begin{array}{c}\text { Eosinophils } \\
(\%)\end{array}$ & $\begin{array}{c}\text { Lymphocytes } \\
(\%)\end{array}$ & $\begin{array}{c}\text { Monocytes } \\
(\%)\end{array}$ \\
\hline Group 1 & $58.4 \pm 3.2^{b}$ & $6.6 \pm 0.5$ & $25.6 \pm 0.5^{\mathrm{a}}$ & $8.4 \pm 0.8^{b}$ \\
\hline $\begin{array}{l}\text { Group } 2 \\
\text { Diabetic control }\end{array}$ & $62.2 \pm 2.4^{\mathrm{a}}$ & $6.6 \pm 0.3$ & $20.4 \pm 0.6^{b}$ & $11.8 \pm 0.2^{\mathrm{a}}$ \\
\hline $\begin{array}{l}\text { Group } 3 \\
5 \% \text { NS }\end{array}$ & $60.8 \pm 4.2^{b}$ & $6.3 \pm 0.2$ & $19.8 \pm 0.6^{b}$ & $10.60 \pm 0.2^{\mathrm{a}}$ \\
\hline $\begin{array}{l}\text { Group } 4 \\
10 \% \text { NS }\end{array}$ & $59.2 \pm 4.4^{b}$ & $6.3 \pm 0.3$ & $19.9 \pm 0.5^{b}$ & $10.30 \pm 0.2^{\mathrm{a}}$ \\
\hline $\begin{array}{l}\text { Group } 5 \\
5 \% \text { SS }\end{array}$ & $59.8 \pm 2.4^{b}$ & $6.9 \pm 0.2$ & $19.9 \pm 0.9^{b}$ & $9.70 \pm 0.3^{\mathrm{a}}$ \\
\hline $\begin{array}{l}\text { Group } 6 \\
10 \% \mathrm{SS}\end{array}$ & $59.3 \pm 2.6^{b}$ & $6.8 \pm 0.3$ & $19.6 \pm 0.6^{b}$ & $10.80 \pm 0.2^{\mathrm{a}}$ \\
\hline $\begin{array}{l}\text { Group } 7 \\
5 \% \mathrm{NS}+5 \% \mathrm{SS}\end{array}$ & $58.5 . \pm 3.6^{b}$ & $6.2 \pm 0.4$ & $19,3 \pm 0.8^{b}$ & $10.40 \pm 0.4^{\mathrm{a}}$ \\
\hline
\end{tabular}

Table.4 Effect of Diets Fortified with Nigella Sativa (NS) and Sesame Seeds (SS) on Blood Glucose (BG) and Insulin Hormone Levels in Diabetic Rats

\begin{tabular}{|lcc|}
\hline Groups & \multicolumn{1}{c|}{$\begin{array}{c}\text { BG } \\
(\mathrm{mg} / \mathrm{dL})\end{array}$} & $\begin{array}{c}\text { Insulin } \\
(\mu \mathrm{U} / \mathrm{ml})\end{array}$ \\
\hline $\begin{array}{l}\text { Group 1 } \\
\text { Normal control }\end{array}$ & $112.7 \pm 1.9^{\mathbf{d}}$ & $45.5 \pm 0.1^{\mathbf{a}}$ \\
\hline $\begin{array}{l}\text { Group 2 } \\
\text { Diabetic control }\end{array}$ & $355.0 \pm 2.1^{\mathbf{a}}$ & $15.3 \pm 0.1^{\mathbf{d}}$ \\
\hline $\begin{array}{l}\text { Group 3 } \\
\text { 5\% NS }\end{array}$ & $322.0 \pm 1.5^{\mathbf{b}}$ & $28.1 \pm 0.1^{\mathbf{c}}$ \\
\hline $\begin{array}{l}\text { Group 4 } \\
10 \% \text { NS }\end{array}$ & $310.5 \pm 2.3^{\mathbf{b c}}$ & $29.2 \pm 0.2^{\mathbf{c}}$ \\
\hline $\begin{array}{l}\text { Group 5 } \\
\text { 5\% SS }\end{array}$ & $215.0 \pm 2.1^{\mathbf{b}}$ & $35.8 \pm 0.2^{\mathbf{b}}$ \\
\hline $\begin{array}{l}\text { Group 6 } \\
\text { 10\% SS }\end{array}$ & $210.5 \pm 3.1^{\mathbf{b}}$ & $39.8 \pm 0.1^{\mathbf{b}}$ \\
\hline $\begin{array}{l}\text { Group 7 } \\
5 \% \text { NS }+5 \% \text { SS }\end{array}$ & $195.0 \pm 1.3^{\mathbf{c}}$ & $43.3 \pm 0.1^{\mathbf{a}}$ \\
\hline
\end{tabular}

Means \pm SD with different superscript letters in the same column are significant at $P<0.05$ using one way ANOVA test. $\mathrm{n}=7$ rats 
Table.5 Effect of Diets Fortified with Nigella Sativa (NS) and Sesame Seeds (SS) on Serum Total Cholesterol (TC) and Triglycerides (TG) Levels in Diabetic Rats

\begin{tabular}{|lcc|}
\hline & \multicolumn{1}{c|}{$\begin{array}{c}\text { TC } \\
\text { Groups }\end{array}$} & $\begin{array}{c}\text { TG } \\
(\mathrm{mg} / \mathrm{dL})\end{array}$ \\
\hline $\begin{array}{l}\text { Group 1 } \\
\text { Normal control }\end{array}$ & $99.50 \pm 3.1^{\mathbf{c}}$ & $79.00 \pm 3.4^{\mathbf{d}}$ \\
\hline $\begin{array}{l}\text { Group 2 } \\
\text { Diabetic control }\end{array}$ & $135.70 \pm 4.1^{\mathbf{a}}$ & $105.00 \pm 5.2^{\mathbf{a}}$ \\
\hline $\begin{array}{l}\text { Group 3 } \\
\text { 5\% NS }\end{array}$ & $122.80 \pm 4.8^{\mathbf{b}}$ & $100.00 \pm 3.1^{\mathbf{b}}$ \\
\hline $\begin{array}{l}\text { Group 4 } \\
10 \% \text { NS }\end{array}$ & $120.60 \pm 3.7^{\mathbf{b}}$ & $98.50 \pm 4.5^{\mathbf{b}}$ \\
\hline $\begin{array}{l}\text { Group 5 } \\
5 \% \text { SS }\end{array}$ & $118.50 \pm 3.6^{\mathbf{b}}$ & $95.50 \pm 4.3^{\mathbf{b}}$ \\
\hline $\begin{array}{l}\text { Group 6 } \\
\text { 10\% SS }\end{array}$ & $104.70 \pm 3.6^{\mathbf{c}}$ & $81.50 \pm 3.6^{\mathbf{c}}$ \\
\hline $\begin{array}{l}\text { Group 7 } \\
5 \% \text { NS +5 \% SS }\end{array}$ & $102.80 \pm 3.8^{\mathbf{c}}$ & $76.50 \pm 3.1^{\mathbf{c}}$ \\
\hline
\end{tabular}

Means \pm SD with different superscript letters in the same column are significant at $P<0.05$ using one way ANOVA test. $\mathrm{n}=7$ rats

Table.6 Effect of Diets Fortified with Nigella Sativa (NS) and Sesame Seeds (SS) on Blood Urea Nitrogen (BUN), Uric Acid (UA) and Creatinine (Cr.) in Diabetic Rats

\begin{tabular}{|c|c|c|c|}
\hline \multicolumn{4}{|c|}{ Parameters } \\
\hline Groups & $\begin{array}{r}\text { BUN } \\
(\mathrm{mg} / \mathrm{dL})\end{array}$ & $\begin{array}{r}\mathrm{UA} \\
(\mathrm{mg} / \mathrm{dL})\end{array}$ & $\begin{array}{c}\mathrm{Cr} . \\
(\mathrm{mg} / \mathrm{dL})\end{array}$ \\
\hline $\begin{array}{l}\text { Group } 1 \\
\text { Normal control }\end{array}$ & $36.3 \pm 1.4^{d}$ & $1.50 \pm 0.01^{\mathrm{a}}$ & $0.75 \pm 0.01^{d}$ \\
\hline $\begin{array}{l}\text { Group } 2 \\
\text { Diabetic control }\end{array}$ & $56.0 \pm 2.4^{\mathrm{a}}$ & $1.49 \pm 0.06^{\mathrm{a}}$ & $1.64 \pm 0.04^{\mathrm{a}}$ \\
\hline $\begin{array}{l}\text { Group } 3 \\
5 \% \text { NS }\end{array}$ & $54.1 \pm 2.6^{b}$ & $1.48 \pm 0.02^{\mathrm{a}}$ & $1.63 \pm 0.02^{b}$ \\
\hline $\begin{array}{c}\text { Group } 4 \\
10 \% \text { NS }\end{array}$ & $52.8 \pm 2.3^{b}$ & $1.49 \pm 0.04^{\mathrm{a}}$ & $1.62 \pm 0.02^{\mathbf{b}}$ \\
\hline $\begin{array}{l}\text { Group } 5 \\
5 \% \text { SS }\end{array}$ & $51.5 \pm 2.1^{\mathrm{b}}$ & $1.50 \pm 0.01^{\mathrm{a}}$ & $1.60 \pm 0.03^{b}$ \\
\hline $\begin{array}{l}\text { Group } 6 \\
5 \% \text { NS }\end{array}$ & $41.4 \pm 2.5^{c}$ & $1.47 \pm 0.05^{\mathrm{a}}$ & $0.94 \pm 0.02^{c}$ \\
\hline $\begin{array}{l}\text { Group } 7 \\
5 \% \text { NS }+5 \% \text { SS }\end{array}$ & $40.6 \pm 1.8^{c}$ & $1.48 \pm 0.01^{\mathrm{a}}$ & $0.92 \pm 0.01^{\mathbf{c}}$ \\
\hline
\end{tabular}

Means \pm SD with different superscript letters in the same column are significant at $P<0.05$ using one way ANOVA test. $\mathrm{n}=7$ rats 
Table.7 Effect of Diets Supplemented with Nigella Sativa (NS) and Sesame Seeds (SS) on Activity of Renal Antioxidant Enzymes Superoxide Dismutase (SOD), Glutathione Peroxidase

(GPx), and Catalase (CAT) in Diabetic Rats

\begin{tabular}{|lccc|}
\hline Parameters & \multicolumn{1}{c}{$\begin{array}{c}\text { SOD } \\
\text { Groups }\end{array}$} & $\begin{array}{c}\text { GPx } \\
(\mathrm{nmol} / \mathrm{min} / \mathrm{mg} \text { protein })\end{array}$ & $\begin{array}{c}\text { CAT } \\
(\mathrm{nmol} / \mathrm{min} / \mathrm{mg} \text { protein })\end{array}$ \\
\hline $\begin{array}{l}\text { Group 1 } \\
\text { Normal control }\end{array}$ & $59.70 \pm 2.22^{\mathbf{a}}$ & $0.69 \pm 0.01^{\mathbf{a}}$ & $0.199 \pm 0.01^{\mathbf{a}}$ \\
\hline $\begin{array}{l}\text { Group (2) } \\
\text { Diabetic control }\end{array}$ & $39.50 \pm 2.68^{\mathbf{d}}$ & $0.28 \pm 0.04^{\mathrm{d}}$ & $0.148 \pm 0.02^{\mathbf{d}}$ \\
\hline $\begin{array}{l}\text { Group 3 } \\
\text { 5\% NS }\end{array}$ & $47.74 \pm 3.26^{\mathbf{c}}$ & $0.35 \pm 0.03^{\mathbf{b}}$ & $0.155 \pm 0.01^{\mathbf{b}}$ \\
\hline $\begin{array}{l}\text { Group 4 } \\
\text { 10\% NS }\end{array}$ & $48.95 \pm 2.38^{\mathbf{c}}$ & $0.45 \pm 0.01^{\mathbf{b}}$ & $0.168 \pm 0.01^{\mathbf{b}}$ \\
\hline $\begin{array}{l}\text { Group 5 } \\
\text { 5\% SS }\end{array}$ & $50.25 \pm 2.73^{\mathbf{b}}$ & $0.55 \pm 0.01^{\mathbf{c}}$ & $0.185 \pm 0.02^{\mathbf{c}}$ \\
\hline $\begin{array}{l}\text { Group 6 } \\
\text { 10\% SS }\end{array}$ & $56.25 \pm 3.23^{\mathbf{b}}$ & $0.62 \pm 0.01^{\mathbf{c}}$ & $0.190 \pm 0.02^{\mathbf{c}}$ \\
\hline $\begin{array}{l}\text { Group 7 } \\
5 \% \text { NS+5\% SS }\end{array}$ & $57.30 \pm 3.53^{\mathbf{b}}$ & $0.65 \pm 0.01^{\mathbf{c}}$ & $0.193 \pm 0.01^{\mathbf{c}}$ \\
\hline
\end{tabular}

Means \pm SD with different letters superscripts (a, b, c, d) in the same column are significant at $P<0.05$ using one way ANOVA test. Unit of GPx $=$ nmol of GSH utilized $/ \mathrm{min} / \mathrm{mg}$ protein. Unit of $\mathrm{CAT}=\mathrm{nmol}$ of $\mathrm{H}_{2} \mathrm{O}_{2}$ utilized $/ \mathrm{min} / \mathrm{mg}$ protein. $\mathrm{n}=7$ rats

Results of the present study showed that diets fortified with Nigella sativa, Sesame seeds and their combination increased body weight gain and improved feed efficiency ratio in diabetic rats. These finding were in agreement with those reported by AbdelSalam (2012) and Alimohammadi et al., (2013) for Nigella sativa and by Oyinloye et al., (2014) for Sesame seeds.

A Previous study showed that the elevated glucose concentrations significantly affected production of cytokines (Reinhold et al., 1994). In accordance, the results presented herein showed changes in the level of the pro-inflammatory cytokine, TNF- $\alpha$, the antiinflammatory cytokine, IL-4, and the chemoattractant cytokine, IL-8, between the diabetic group and the other groups. The changes in the TNF- $\alpha$ level could be due to the changes in insulin secretion, where insulin modulates the development of the inflammatory reaction to allergen challenge by its ability to modulate the production/release of TNF- $\alpha$. (Martins et al.,
2010; and Abdel-Salam, 2012). The later author reported that black seeds produced an immunomodulatory effect in alloxandiabetic albino rats. In gamma-irradiated rats, Assayed (2010) found that Nigella sativa produced radio-protective and immunostimulant effects. Leukocytes proliferation results suggested that alloxandiabetic rats had an increase in granulocytes and monocytes, and a decrease in lymphocytes proliferation. On the other hand, the diabetic rats treated with Nigella sativa and Sesame seeds showed modulations in these changes.

The present results revealed that diet supplemented with Nigella sativa and Sesame seeds significantly increased serum insulin and decreased blood glucose levels in diabetic rats. These antidiabetic and hypoglycemic effects of Nigella sativa and Sesame seeds agreed with the previous reports by Alimohammadi, et al., (2013) for Nigella sativa and by Wikul et al., (2012) for Sesame seeds. 
Feeding diet supplemented with Nigella sativa and Sesame seeds produced hypocholesterolemic and hypolipidemic activities. These results were in agreement with those reported by Ibrahim et al., (2014) for Nigella sativa and by Biswas et al., (2010) for Sesame seeds.

The present results showed that Nigella sativa and Sesame seeds feeding to diabetic rats produced nephroprotective and renal tissue antioxidant effects. These effects were previously reported for Nigella sativa (Dollah et al., 2013 and Erboga et al., 2015) and for Sesame seeds (Oyinloye et al., 2014).

In conclusion, the results denote that diet supplementation with Nigella sativa and Sesame seeds and their combination exhibits good immunostimulant, hypoglycemic. Hypolipidemic, nephroprotective and antioxidant activities in alloxan - diabetic rats. The study recommends that intake of baked foods and sweets supplemented with both Nigella sativa and Sesame seeds may be beneficial for patient with type 2 diabetes mellitus. In addition, isolation of bioactive constituents from Nigella sativa and Sesame seeds is necessary to search for safe and bioactive natural substances to be used for therapy of diabetes mellitus.

\section{References}

Abdel-Salam, B.K. (2012): Immunomodulatory effects of black seeds and garlic on alloxan-induced diabetes in albino rat. Allergol. Immunopathol.; 40(6):336-340.

Ahmad, S. and Beg, Z.H. (2013): Hypolipidemic and antioxidant activities of thymoquinone and limonene in atherogenic suspension fed rats. Food Chem.; 138(3):11161124.
Akhtar, M.S. and Ali, M.R. (1984): The study of hypoglycemic activity of Cuminum nigrum seeds in normal and alloxan diabetic rabbits. Planta Med.; 2:81-85.

Alimohammadi, S.; Hobbenaghi, R.; Javanbakht, J.; Kheradmand, D.; Mortezaee, R.; Tavakoli, M.; Khadivar, F. and Akbari, H. (2013): Protective and antidiabetic effects of extract from Nigella sativa on blood glucose concentrations against streptozotocin (STZ)-induced diabetic in rats: an experimental study with histopathological evaluation. Diagn. Pathol. ; 15; 118:137.

Ashok, D.C.; Shrimant, N.P.; Panadeep, M.G. and Akalpita, U.A.(2007): Optimization of alloxan dose is essential to induce stable diabetes mellitus for long period. Asian J. Biochem.; 2(6):402-408.

Asgary, S.; Sahebkar, A. and GoliMalekabadi, N. (2015): Ameliorative effects of Nigella sativa on dyslipidemia. J. Endocrinol. Invest.; 38(10): 1039-1046.

Assayed, M.E. (2010): Radio-protective effects of black seed (Nigella sativa) oil against hemopoietic damage and immunosuppression in gammairradiated rats. Immunopharmacol. Immunotoxicol.; 32(2): 284-296.

Badary, O.A.; Nagi, M.N.; Al-Shabanah, O.A.; Al-Sawaf, H.A.; Al-Sohaibani, M.O.; Al- Bekairi, A.M. (1997): Thymoquinone ameliorates the nephrotoxicity induced by cisplatin in rodents and potentiates its antitumor activity. Canadian J. Physiol. Pharmacol.; 75 (12): 1356-1361.

Biswas, A.; Dharm, P. and Ghosh, S. (2010): Antihyperlipidemic effect of sesame (Sesamum indicum L.) protein isolate in rats fed a normal and high 
cholesterol diet. J. Food Sci.; 75(9): 274-279.

Dollah, M.A.; Parhizkar, S. and Izwan. M. (2013): Effect of Nigella sativa on the kidney function in rats. Avicenna J. Phytomed. ; 3(2):152-158.

El-Feki, M.A.; Radwan, Z.A.; AbdelMoneim, A.A. and Salah, F. (1997): Effects of Nigella sativa and fish oil in alloxan diabetic rats: Immunological studies. J. Egyp. Ger. Soc. Zool.; 23:161-186.

Erboga, M.; Kanter, M.; Aktas, C.; Sener, U.; Erboga, Z.; Bozdemir D.Y. and Gurel, A. (2015): Thymoquinone Ameliorates Cadmium-Induced Nephrotoxicity, Apoptosis, and Oxidative Stress in Rats is Based on its Anti-Apoptotic and Anti-Oxidant Properties. Biol. Trace Elem. Res.; 1: $1-8$.

Fossati, P.; Prencipe, L. and Berti, G. (1980): Use of 3, 5 dichloro-2hydroxyl benzene sulfonic acid /4amylphenazone chromogenic system in direct enzymatic assay of uric acid in serum and urine. Clin. Chem.; 26: 227-231.

Gale, E.M. and Anderson, J.V. (2009): Diabetes mellitus and other disorders of metabolism. In: Kumar P., Clark, M. (Edrs), Kumar and Clark Clinical Medicine. The 7th Edition, Spain, Saunders Elsevier, Page 1029-1073.

Gali-Muhtasib, H.; Roessner, A. and Schneider-Stock, R. (2006): Thymoquinone: a promising anticancer drug from natural sources. Int. J. Biochem. Cell Biol.; 38 (8):12491253.

Haq, A.; Abdullatif, M., Lobo, P.I.; Khabar, K.S.; Sheth, K.V. and Al-Sedairy, S.T. (1995): Nigella sativa: effect on human lymphocytes and polymorphonuclear leukocyte phagocytic activity. Immunopharm.; 30(2): 147-155.

Houghton, P.J.; Zarka, R.; De-las, H. B.; and Hoult, J.R. (1995): Fixed oil of Nigella sativa and derived thymoquinone inhibit eicosanoid generation in leukocytes and membrane lipid peroxidation. Planta Medica; 61(1):33-36.

Husdan, H. and Rapoport, A. (1968): Estimation of creatinine by Jaffe reaction method. Clin. Chem.; 14: 222-228.

Ibrahim, R.M.; Hamdan, N.S.; Mahmud, R.; Imam, M.U.; Saini, S.M.; Rashid, S.N. Abd Ghafar, S.A.; Latiff, L.A and Ismail, M.(2014): A randomized controlled trial on hypolipidemic effects of Nigella Sativa seeds powder in menopausal women. J. Transl. Med.; 12:82- 89.

Inci, M.; Davarci, M.; Motor. S.; Yalcinkaya, F.R. ; Nacar; E. ; Aydin, M., Sefil, N.K. and Zararsiz, I. (2013): Anti-inflammatory and antioxidant activity of thymoquinone in a rat model of acute bacterial prostatitis. Hum. Exp. Toxicol.; 32:354-361.

Itariu, B.K. and Stulnig, T.M. (2014): Autoimmune aspects of type 2 diabetes mellitus. Gastroentrol.; 60(3): 189-196.

Jacob, N.J. and Van-Denmark, P.J. (1963): A chemical method for the determination of triglycerides. Arch. Biochem. Biophys., 88: 250-255.

Jin, C.; Henao-Mejia, J. and Flavell, R.A. (2013): Innate immune receptors: key regulators of metabolic disease progression. Cell Metab.; 17(6): 873882.

Kaleem, M.; Kirmani, D.; Asif, M.; Ahmed, Q. and Bano, B. (2006): Biochemical effects of Nigella sativa $L$ seeds in diabetic rats. Indian J. Exp. Biol.; 44(9):745-748. 
Luis-Rodríguez, D.; Martínez-Castelao, A.; Gorriz, J.L.; De-Alvaro, F. and Navarro-Gonzalez, J.F. (2012): Pathophysiological role and therapeutic implications of inflammation in diabetic nephropathy. World J. Diabetes; 15:7-18.

Ma, J.Q.; Ding, J.; Zhang, L. and Liu, C.M. (2014): Hepatoprotective properties of sesamin against $\mathrm{CCl} 4$ induced oxidative stress-mediated apoptosis in mice via JNK pathway. Food Chem. Toxicol.; 64:41-48.

Mahendra K.C. and Singh, S.A. (2015): Bioactive lignans from Sesame (Sesamum indicum L.): evaluation of their antioxidant and antibacterial effects for food applications. J. Food Sci. Technol.; 52(5):2934-2941.

Martins, J.O.; Ferracini, M.; Anger, D.B.; Martins, D.O.; Ribeiro, L.F. and Sannomiya P. (2010): Signaling pathways and mediators in LPSinduced lung inflammation in diabetic rats: role of insulin. Shock; 33:76-82.

Mirmiran, P.; Bahadoran, Z.; Golzarand, M.; Rajab, A. and Azizi, F. (2013): Ardeh (Sesamum indicum) could improve serum triglycerides and atherogenic lipid parameters in type 2 diabetic patients: a randomized clinical trial. Arch Iran Med.;16(11):651-656.

Miyawaki, T.; Aono, H, ;Toyoda-Ono, Y.; Maeda, H.; Kiso, Y. and Moriyama, K. (2009): Antihypertensive effects of sesamin in humans. J. Nutri. Sci. Vitaminol.; 55(1):87-91.

Okamoto H. (1985): Ultrastructural aspects of streptozotocin cytotoxicity on rat pancreatic islets in vitro. BioEssays; 2:15-21

Oyinloye, B.E.; Nwozo, S.O.; Amah, G.H.; Awoyinka, A.O.; Ojo, O.A.; Ajiboye, B.O. and Tijani, H.A. (2014): Prophylactic effect of aqueous extract of Sesamum indicum seeds on ethanol-induced toxicity in male rats. Nutri. Res. Pract. ; 8(1):54-58.

Paglia, D.E, and Valentine, W.N. (1979): Determination of glutathione peroxidase in tissue by UV method. J. Lab. Clin. Med.; 70:158-169.

Patton, C. J. and Crouch S.R. (1977): Enzymatic colorimetric method for determination of urea in serum. Anal. Chem.; 49: 464-465.

Randhawa, M.A. and Alghamdi, M.S. (2011): Anticancer activity of Nigella sativa (black seed) - A review. Am. J. Clin. Med.; 39(6):1075-1091.

Ratliff, C.R. and Hall, F. (1973): A new method for direct colorimetric determination of serum cholesterol. Cited in Laboratory Manual of Clinical Biochemistry, Scoot and White Memorial Hospital publication, Texas, USA.

Reinhold, D.; Bank, U.; Buhling, F.; Lendeckel, U.; Ulmer, A.J. and Flad, H.D. (1994): Transforming growth factor h1 (TGFh1) inhibits DNA synthesis of PWM-stimulated PBMC via suppression of Il-2, IL-6 production. Cytokine. 6:382-388.

Reeves, P.G.; Nielson, F.H. and Fahmy, G.C. (1993): Reports of the American Institute of Nutrition, ADHOC willing Committee on reformulation of the AIN 93, rodent diet. J. Nutri.; 123: 1939-1951.

Schalm, O.W.; Jain, N.C. and Carroll, E.J. (1975): Veterinary Hematology. The 3 rd Edition, Lea and Febiger, Philadelphia, U.S.A., Page 42-54.

Siao, A.C.; Hou, C.W.; Kao, Y.H.; Jeng, K.C.; Siao, A.C.; Hou, C.W.; Kao, Y.H. and Jeng, K.C. (2015): Effect of sesamin on apoptosis and cell cycle arrest in human breast cancer mcf-7 cells. Asian Pac. J. Cancer Prev.; 16(9):3779-3783. 
Sinha, KA. (1972): Colorimetric assay of catalase enzyme. Anal Biochem; 47: 389- 394.

Siest, G., Henny, F. and Schiele, F. (1981): Enzymatic determination of glucose. Interpret, Exam. Lab.; 2: 206-213.

Snedecor, G.W. and Cochran, W.G. (1986): Statistical Methods, 7th Edition, Iowa State University Press, Ames, USA, Page 90.

Sreeramulu, D. and Raghunath. M. (2010): Antioxidant activity and phenolic content of roots, tubers and vegetables commonly consumed in India. Food Res Int.; 43: 1017-1020.

Spitz, D.R. and Oberley, L.W. (1989): An assay for superoxide dismutase activity in mammalian tissue homogenates. Anal. Biochem.; 179: 818.

Sturza, A.1.; Duicu, O.M.; Vaduva, A.; Dănilă, M.D., Noveanu, L., Varró, A., Muntean, D.M. (2015): Monoamine oxidases are novel sources of cardiovascular oxidative stress in experimental diabetes. Can. J. Physiol. Pharmacol.; 12:1-7.

Sultan, M.T.; Butt, M.S.; Karim, R.; Iqbal, S.Z.; Ahmad; S.; Zia-Ul-Haq, M. , Aliberti, L., Ahmad, A.N. and De Feo, V. (2014): Effect of Nigella sativa fixed and essential oils on antioxidant status, hepatic enzymes, and immunity in streptozotocin induced diabetes mellitus. BMC Complement. Altern. Med. 17; 14:193. Doi: 10.1186/14726882-14-193.

Wikul, A.; Damsud, T., Kataoka, K. and Phuwapraisirisan, P. (2012): Pinoresinol is a putative hypoglycemic agent in defatted Sesame (Sesamum indicum) seeds though inhibiting $\alpha$ glucosidase. Bioorg. Med. Chem. Lett.; 22(16):5215-5217.

Yallow, R. and Bauman, W.A. (1983): Plasma insulin in health and disease. In: Diabetes Mellitus: Theory and Practice. Edrs: Ellenberg M and Rifkin H. Excerpta Medica; 15:119- 120.

\section{How to cite this article:}

Thanaa A.A. Ibrahiem. 2016. Beneficial Effects of Diet Supplementation with Nigella sativa (Black Seed) and Sesame Seeds in Alloxan-Diabetic Rats. Int.J.Curr.Microbiol.App.Sci. 5(1): 411-423. http://dx.doi.org/10.20546/ijcmas.2016.501.041 